\title{
Reevaluation of Holocene faulting at the Kaysville site, Weber segment of the Wasatch fault zone, Utah
}

\author{
James P. McCalpin ${ }^{1}$ \\ Department of Geology, Utah State University, Logan
}

\author{
Steven L. Forman \\ Byrd Polar Research Center and Department of Geology, Ohio State University, Columbus
}

Mike Lowe

Utah Geological Survey, Salt Lake City

\begin{abstract}
The 1978 Kaysville, Utah, trench excavated by Swan and others (1980) across a large graben of the Weber segment of the Wasatch fault zone was reexcavated in 1988 to reevaluate the timing and nature of Holocene faulting. Relogging of the trench reveals evidence for five or six faulting events younger than the Provo phase of Lake Bonneville (circa $13,000{ }^{14} \mathrm{C}$ years B.P.). Geometric reconstruction of net vertical offset in the last three events suggests a variation in coseismic vertical displacement at this site, ranging from a net of $\mathbf{1 . 4 - 3 . 4} \mathrm{m}$ per event. The three latest faulting events occurred at shortly before $0.6-0.8 \mathrm{ka}$, 2.840.7 ka, and circa 3.8-7.9 ka. Earlier events cannot be directly dated because older graben-fill sediments yielded thermoluminescence ages older than the time of deposition, and some scarp-derived colluvial wedges beneath the trench floor were not exposed. The two younger faulting events we recognize at Kaysville correlate reasonably well with faulting events on the same segment $25 \mathrm{~km}$ north near East Ogden, Utah, at circa 0.8-1.2 ka and 2.5-3.0 ka (Forman and others, 1991), whereas the earlier Kaysville event is significantly older than the earliest (3.5-4.0 ka) event dated at East Ogden. The 3.5-4.0 ka ground rupture recognized at East Ogden may have died out at a subsegment boundary between the two trench sites within the 61-km-long Weber segment.
\end{abstract}

\section{INTRODUCTION}

The Wasatch fault zone (WFZ) was a target of early paleoseismological research utilizing trench exposures to describe the sedimentologic record of normal fault displacements and to date Holocene faulting events. One of the earliest excavations (1978) near Kaysville, Utah, on the

\footnotetext{
${ }^{1}$ Now at: GEO-HAZ Consulting, Incorporated, Estes Park, Colorado.
}

Copyright 1994 by the American Geophysical Union.

Paper number 93TC02067.

0278-7407/94/93TC02067\$10.00
Weber segment of the WFZ (as defined by Machette et al, [1991, 1992]) revealed compelling evidence for multiple surface faulting events during the Holocene [Swan et al., $1980,1981]$. Two concepts developed from interpretations of this trench later became part of the foundation of modern paleoseismology. The first concept is that individual paleoseismic ruptures are often recorded by discrete wedgeshaped deposits of scarp-derived colluvium [Hanson and Schwartz, 1982]. The second concept is that faults (or fault segments) rupture during large earthquakes within a characteristic magnitude range ("characteristic earthquakes" [Schwartz and Coppersmith, 1984]). Despite these important concepts generated by the early paleoseismic research, the chronology of paleoseismic events at Kaysville was poorly constrained by a single radiocarbon age from outside the main fault zone penetrated by the 1978 excavation.

Several improved paleoseismic techniques, developed on the WFZ and other faults in the past decade, were applied to the Kaysville site in this study. Radiocarbon dating of soil horizons with a low organic carbon content, using conventional or accelerator mass spectroscopy (AMS) techniques, has been successful in reconstructing Holocene faulting chronologies elsewhere on the WFZ (summarized by Machette et al. [1991, 1992]). Thermoluminescence dating, used in conjunction with ${ }^{14} \mathrm{C}$ dating, has provided additional constraints on faulting for the WFZ [Forman et al., 1989, 1991). In addition, recent work on the sedimentation patterns in normal fault zones [Nelson, 1992; McCalpin et al., 1993] and on geometry of normal surface ruptures [McCalpin, 1983, 1987] were used to refine the faulting chronology originally proposed by Swan et al. [1980].

The Kaysville site was attractive because previous trenching [Swan et al., 1981] had documented a thick, finegrained graben fill that might yield additional ${ }^{14} \mathrm{C}$ and TL age constraints on Holocene faulting. Our new data on fault timing and displacement add to recent mapping [Nelson and Personius, 1990, in press] and geochronologic work [Nelson, 1988; Forman et al., 1991; Machette et al., 1992] from two trench sites farther north on the Weber segment, which at $61 \mathrm{~km}$ long is the second-longest segment of the WFZ. In particular, we attempt to correlate the three latest Holocene 
ruptures at Kaysville with those dated at sites $25 \mathrm{~km}$ farther north on the same segment [Forman et al., 1991].

\section{GEOMORPHIC SETTING}

The Kaysville site is about $3 \mathbf{~ k m}$ east-southeast of the city of Kaysville in Davis County, Utah, on the Weber segment of the Wasatch fault zone between Baer Creek and Shepard Creek (Figure 1). Here the WFZ is expressed as a $22-\mathrm{m}$ high west-facing scarp with a shallow flat-floored graben as much as $30 \mathrm{~m}$ wide at its base (Figure 2). The highest Bonneville shoreline (circa 15 to $17 \mathrm{ka}$ ) and the main Provo shoreline (circa 13 to $14 \mathrm{ka}$ ) of the Bonneville lake cycle [Scott et al., 1983; Currey and Oviatt, 1985] both lie above the fault scarp. The geomorphic and stratigraphic setting of the trench are detailed by Swan et al. [1980].

Our 39-m-long trench was excavated in October, 1988, parallel to but offset $2 \mathrm{~m}$ south of Swan et al.'s [1981] trench A; both trench walls exposed undisturbed sediment. Our main objective was to expose a maximum vertical thickness of graben sediment, so the new trench was excavated $5.5 \mathrm{~m}$ deep with a track-mounted backhoe, or about 1 to $1.5 \mathrm{~m}$ deeper than the 1978 trench.

\section{STRATIGRAPHY AND STRUCTURE IN THE TRENCH}

The history of repeated normal surface-faulting is contained mainly in the stratigraphy of scarp-derived colluvial deposits and correlative graben sediment [Hanson and Schwartz, 1982; Schwartz and Coppersmith, 1984; McCalpin, 1989; Machette et al., 1992). To understand how datable deposits in fault zone trenches relate to individual paleoseismic events, we must understand the depositional environment of each stratigraphic unit and its relation to fault-induced sedimentation. This reliance of tectonic interpretation on sedimentary facies relations is common in basin-scale analyses of rift basins and half-grabens [e.g., Leeder and Gawthorpe, 1987; Blair and Bilodeau, 1988] and its application on a small scale in fault trenches is similar. The detailed unit descriptions in Table 1 support our inferences on depositional environment and are the key to unraveling the chronology of faulting at this and similar sites along the WFZ.

\section{Stratigraphy}

Stratigraphic units in the 1988 trench were subdivided into nine major lithofacies based on differences in grain size and sedimentary structures (Figure 3, Table 1). The subdivision of lithologic units and interpretation of depositional environment incorporate some ideas from recent lithofacies models of fault-scarp environments [Nelson, 1992]. Colluvial units can be divided into proximal (near the main fault) and distal facies, or into debris facies (deposited by gravity and debris flows) or wash facies (deposited by slopewash and creep).

Deposits exposed in the trench fall into two broad categories, either graben fill (from oldest to youngest, units $3,4,5,6 \mathrm{~A}-6 \mathrm{~B}, 7 \mathrm{~A}-7 \mathrm{C}, 8$, and $9 \mathrm{~A}$ ) or scarp-derived colluvium (units 6D-6E, 7D-7E, and 9B-9D). These two classes of deposits interfinger to form discrete genetic couplets. Each couplet consists of post faulting, laterally accreting scarpbase colluvium, which progrades valleyward and interfingers with finer, vertically accreting, sag pond sediment deposited in graben or back tilted areas created by complex surface deformation [see Slemmons, 1957]. Each couplet (e.g., Figure 3, units $6 \mathrm{C}$ and $6 \mathrm{D}$ interfingering with unit $6 \mathrm{~A}$ or units $7 \mathrm{D}$ and $7 \mathrm{E}$ grading into unit 7A) is separated from the overlying couplet by a soil horizon that represents a period of relative landscape stability between the surface-faulting events. Table 1 lists the sedimentologic characteristics needed to identify discrete couplets and their components and to estimate the degree of predepositional sunlight exposure to assist the interpretation of TL age estimates.

\section{Structure}

Two deformation zones exist in the trench, a main normal fault zone at the eastern end of the trench and a broader zone of tension fissures and small normal faults in the western end (Figure 3 ). The main fault consists of a highly sheared zone of lacustrine sand up to $40 \mathrm{~cm}$ wide along

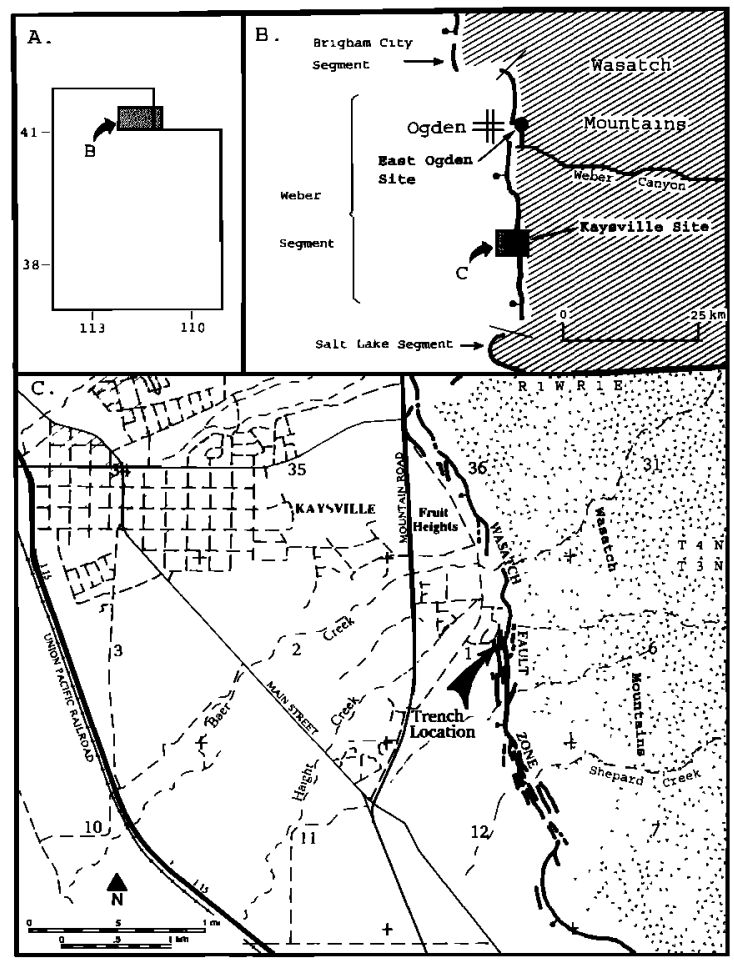

Fig. 1. Kaysville trench site, Wasatch fault zone, Utah: (a) regional location, (b) location of the Kaysville site in the Weber segment, and other segments and locations mentioned in text, and (c) local area map. Stipple pattern shows uplifted rocks of the Wasatch Range; dashed lines show roads; dashed and dotted lines show intermittent streams. Fault scarps are adopted from Nelson and Personius [1990]. 


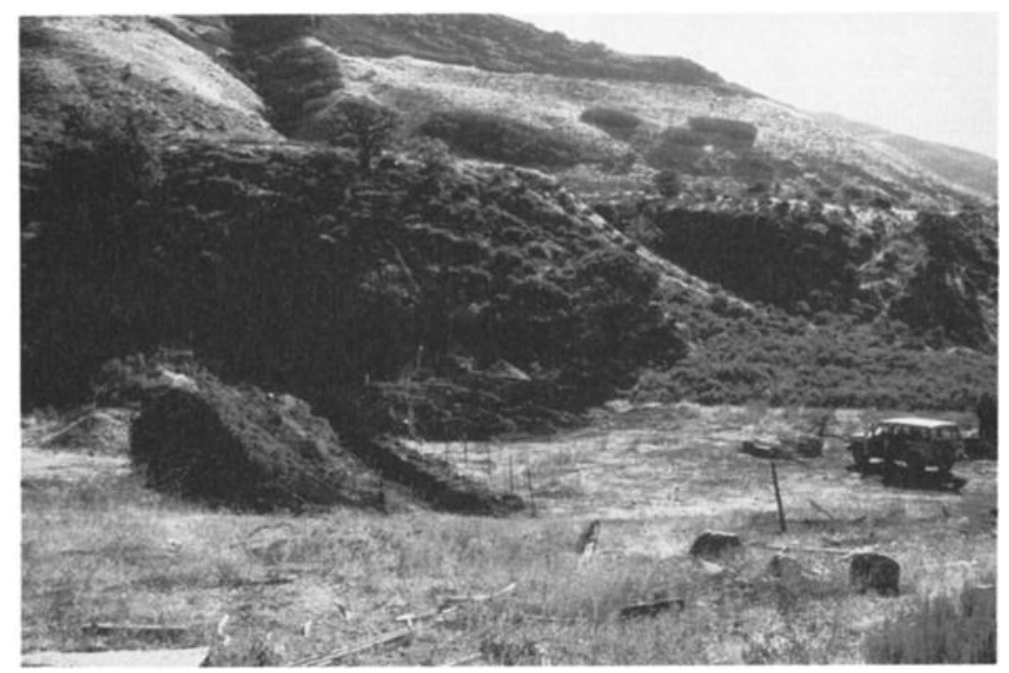

Fig. 2. Photograph of the Kaysville fault scarp and trench, looking east. Scarp height at left center (shadowed) is $22 \mathrm{~m}$; width of graben in foreground is $30 \mathrm{~m}$. The gully to the right of the trench is a local source of sediment for the graben. Note large alluvial fan at mouth of gully. Much of the fan was deposited historically and grades into graben fill unit 8B (Figure 3). The sparsely vegetated slope above the fault scarp in the background is bounded by the Bonneville highstand shoreline (upper boundary) and the Provo shoreline (lower boundary).

which most Holocene displacement has presumably occurred. The fault strikes $N 00^{\circ}-09^{\circ} \mathrm{E}$ and dips $68^{\circ}-70^{\circ} \mathrm{W}$. High-resolution seismic-reflection surveys [Stephenson et al., 1993] suggest the fault dip decreases to $45^{\circ}$ at $25 \mathrm{~m}$ depth. The $25^{\circ}$ steepening of the main fault dip near the surface, which is typical of normal faults, results in creation of void space during each faulting event and provides space into which graben deposits are backtilted or downdropped.

A fissure zone extends from $11 \mathrm{~m}$ on the trench log (Figure 3) to beyond the western end of the trench. According to the $\log$ of Swan et al. [1980] another $9 \mathrm{~m}$ of faulted and fissured graben fill extends west beyond our trench to a major antithetic fault zone, which defines the western edge of the present topographic graben. The densely fissured area (Figure 3, 5-6 m on horizontal scale) corresponds to a tilt "hingeline" separating faulted but nearly horizontal graben deposits (to the west) from progressively east-tilted, relatively unfaulted graben deposits to the east. This Holocene hingeline is different from the older hingeline defined by Swan et al. [1980, their Figure 4] about $60 \mathrm{~m}$ west of the main fault, which affects only lithofacies 2 . Two kinds of structures exist in the fissure zone, smalldisplacement normal faults and open tension fissures filled with organic soil material. The small-displacement faults form a zone of closely spaced (0.5-2.0 m), conjugate normal faults that dip $60^{\circ} \mathrm{W}$ and $80^{\circ} \mathrm{E}$, respectively. Conjugate faults are mainly developed in the moist, massive silt of lithofacies 3. This cohesive unit probably responded to eastwest stretching over the Holocene tilt hingeline by conjugate shear, whereas the overlying gravelly units may have extended by developing vertical tension fissures more suggestive of dry, brittle fracture. The fissures are filled with friable, organic-rich, dark brown, stone-free silt and sand that is similar to the overlying soil (S3). We interpret the fissure-filling material as surface $A$ horizon material that fell into open fractures from soil S3 after a faulting event.

Between the main fault zone and the fissure zone, the trench exposed an east-tilted, unfaulted block of Holocene graben-fill sediment. The eastward dip of beds in the sequence steepens with increasing depth, indicating greater tilt of the older beds (Figure 3). The differences between the dip of beds provide one basis for reconstructing the timing of faulting (discussed later). The eastward dip of individual beds also increases toward the main fault zone. Projection of the Provo alluvial fan/graben fill contact (the lithofacies $2 B / 3$ a contact) to the main fault zone suggests that the graben fill may reach a thickness of $11 \mathrm{~m}$ at the main fault.

\section{GEOCHRONOLOGY}

\section{Radiocarbon Dating}

One way to constrain the timing of fault events is to date organic material from A horizons of paleosols that were buried by colluvium shed from a fault scarp [Schwartz and Coppersmith, 1984; Nelson and Van Arsdale, 1986; Forman et al., 1989, 1991; Machette et al., 1992]. Fortunately, two buried paleosols (S1 and S3) with well-preserved A horizons occur in the graben sediment. The upper $10 \mathrm{~cm}$ of the $A$ horizons of soils S1 and S3 were sampled for conventional radiocarbon dating (Table 2 ). The $<125$ um fraction of these samples was isolated and organic matter concentrated following the procedure of Kihl [1975]. An estimated mean residence time (MRT) of $300 \pm 200$ years was subtracted from all laboratory ${ }^{14} \mathrm{C}$ ages (Table 2), following the 


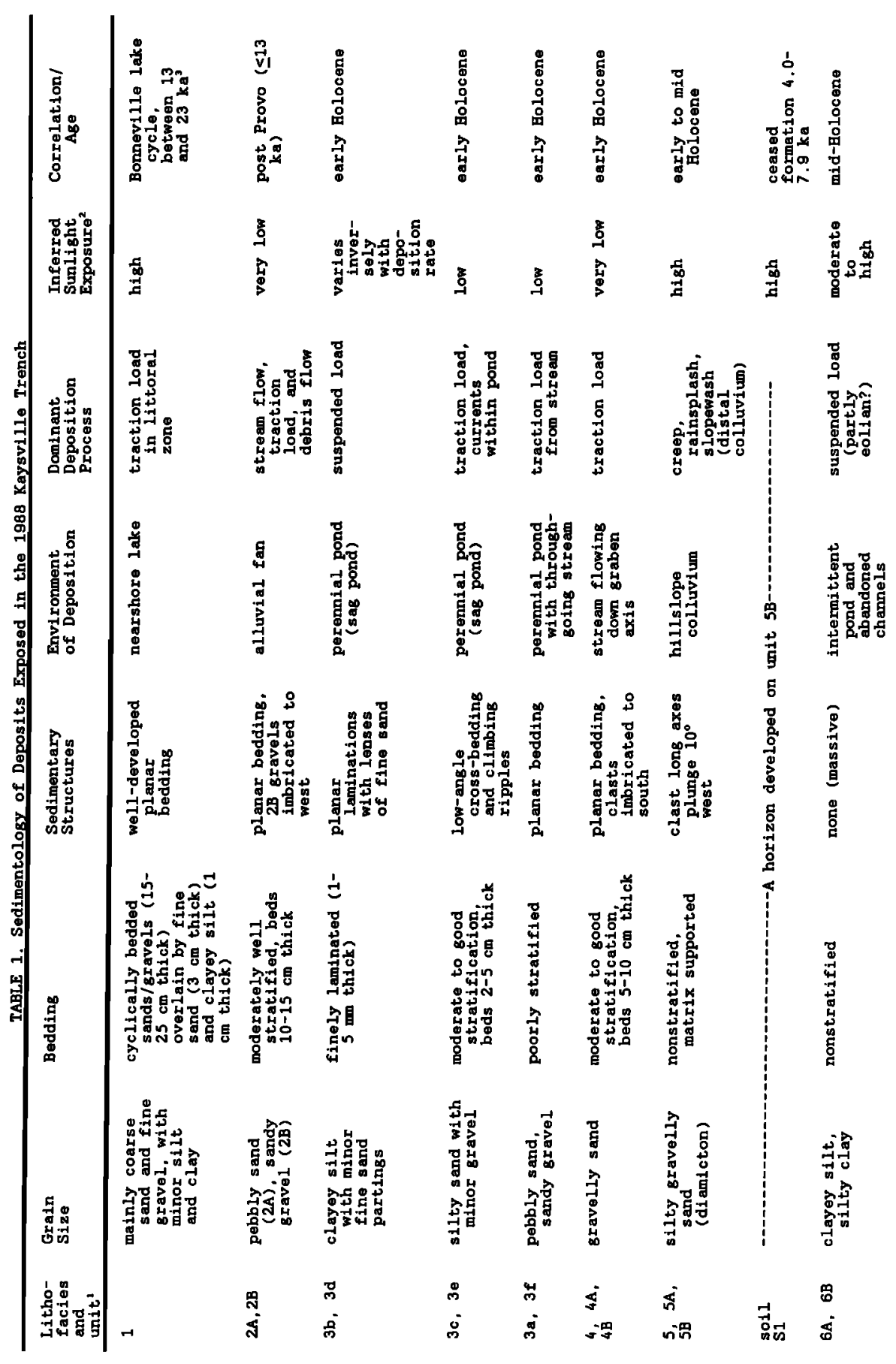




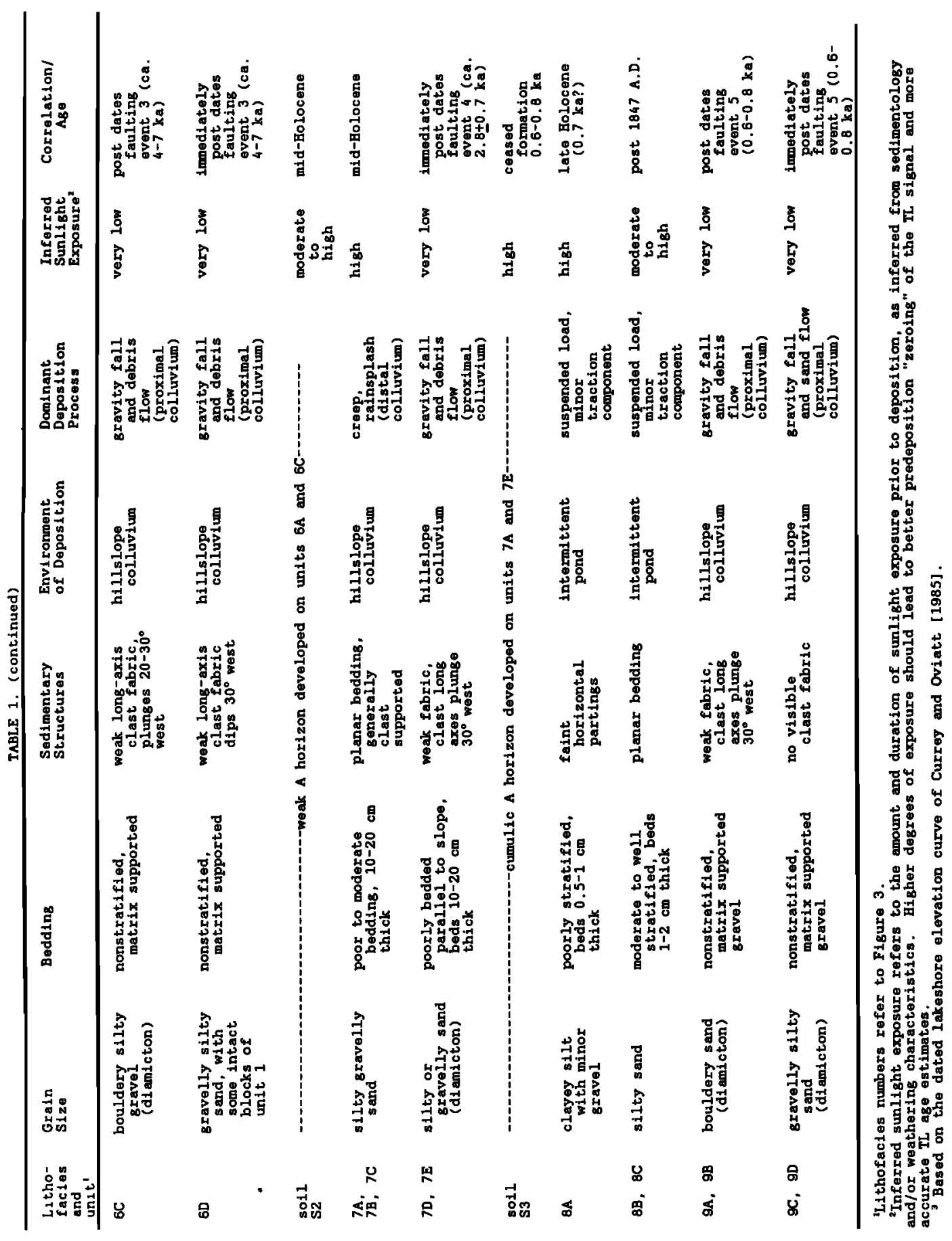




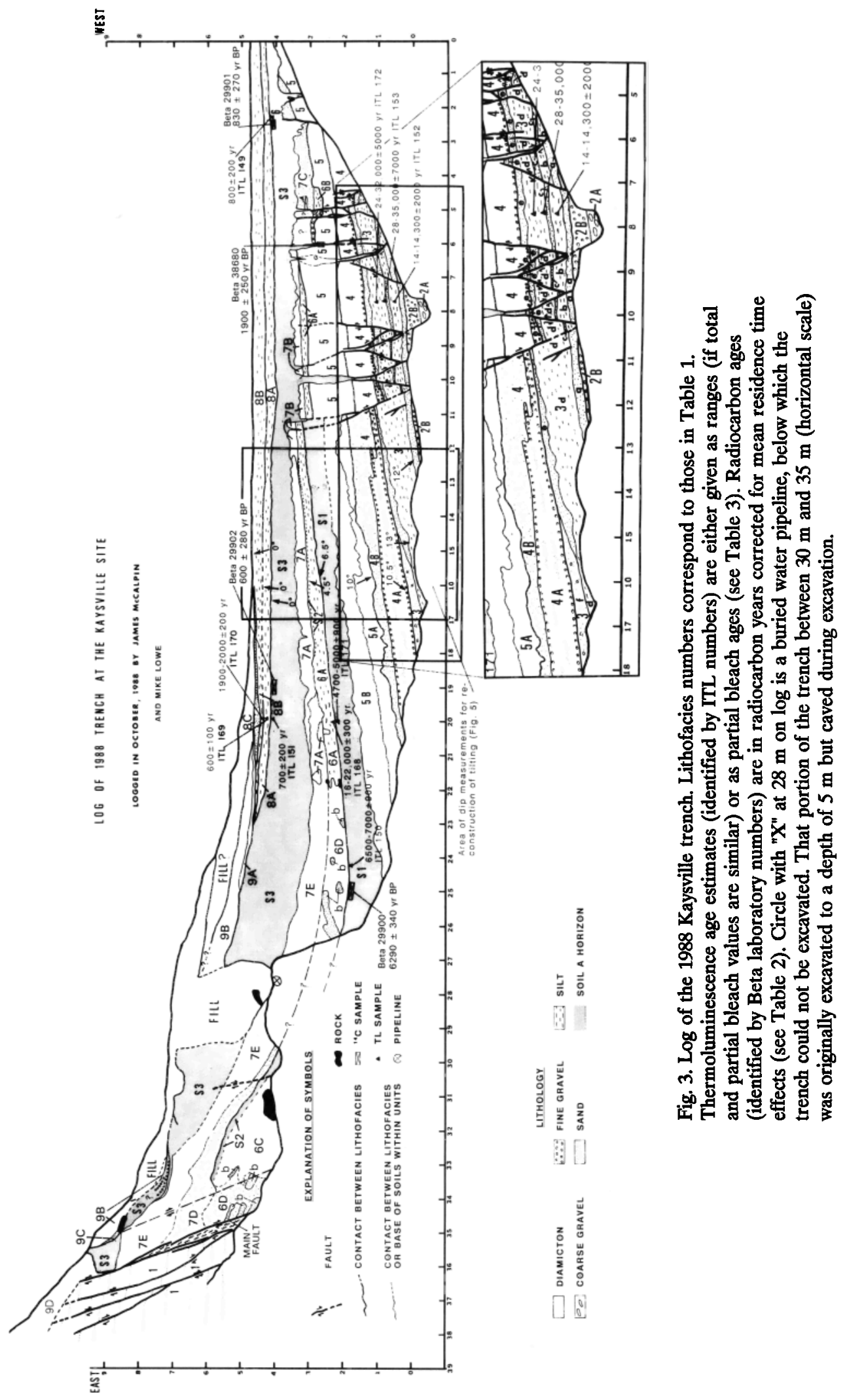




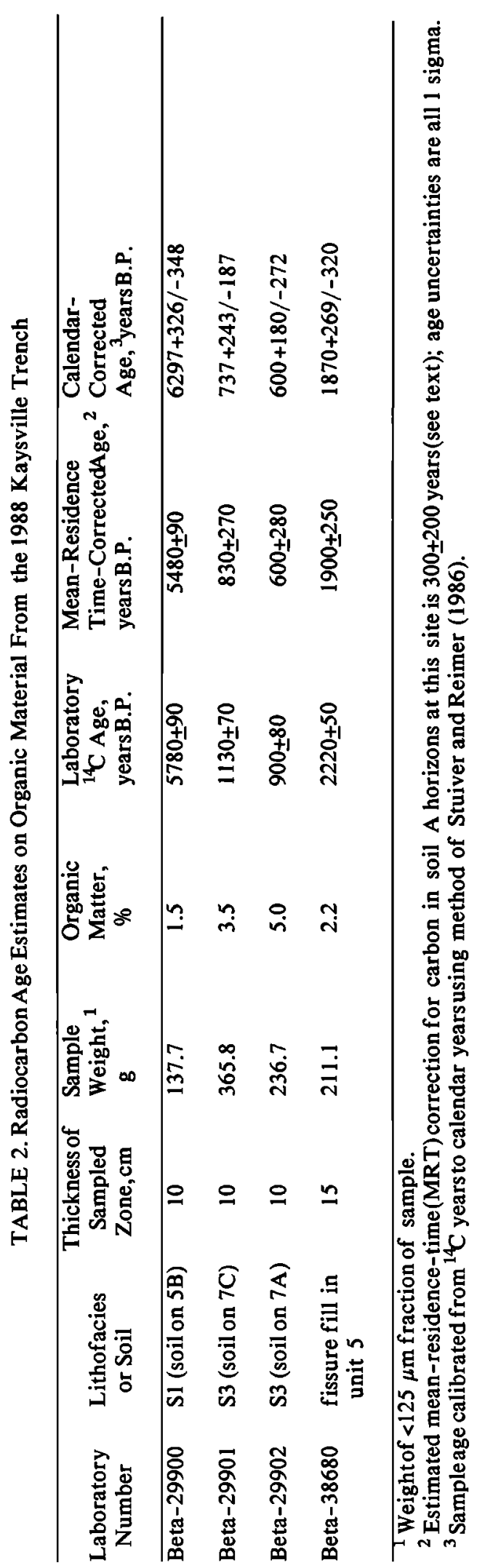

procedure of Machette et al. [1992, Appendix]. These ages were then calendar-corrected using the method of Stuiver and Reimer [1986].

\section{Thermoluminescence Dating}

A relatively new technique to constrain the timing of faulting events is thermoluminescence dating [McCalpin, 1986; Forman et al., 1989, 1991; McCalpin and Forman, 1991]. Exposure of mineral grains to ionizing radiation after burial causes mineral lattice damage that results in luminescence upon heating. Sediment that receives prolonged light exposure prior to deposition, for example loess and A horizons of soils, is particularly suitable for TL dating. Water-lain sediment, particularly fluvial sediment, often yields overestimates in age because of insufficient light exposure prior to deposition [Forman, 1989]. The $4 \mu \mathrm{m}-11$ $\mu \mathrm{m}$ (silt) fraction was isolated for TL analyses following the procedures outlined by Forman et al. [1989, 1991]. All samples were analyzed by the total- and partial-bleach techniques, assuming a mean water content of $15 \%+5 \%$ (Table 3). For a broader overview of TL dating applied to Quaternary deposits, the reader is referred to Forman [1989] and Forman and Machette [1991].

\section{Ages of Trench Soils and Deposits}

Both soil A horizons and fluvial/lacustrine sediments were sampled for thermoluminescence dating. The general accuracy of TL age estimates is evaluated by comparison to radiocarbon ages on soils $S 1$ and $S 3$, which yielded ${ }^{14} \mathrm{C}$ ages of circa $6.3 \pm \quad 0.3 \mathrm{ka}$ and $0.6-0.8 \pm 0.2 \mathrm{ka}$, respectively. One sample from the $A$ horizon of soil 3 yielded TL ages of $0.7 \pm 0.2 \mathrm{ka}$ and $0.8 \pm 0.1 \mathrm{ka}$ by the partial- and total-bleach techniques, respectively, which is in good agreement with the radiocarbon ages. The four numerical ages from the upper $10 \mathrm{~cm}$ of soil S3 and the one age from unit $8 \mathrm{~A}$ provide limits on the time of burial of soil S3 by renewed sag pond deposition. In the western part of the graben (Figure 3, samples ITL 149, Beta-29901), soil S3 was buried at a mean age of $815+287$ years B.P. In contrast, numerical ages from the top of soil S3 at the toe of the fault scarp (Figure $3,20 \mathrm{~m}$ on horizontal scale) indicate burial occurred after $650 \pm 344$ years B.P. (mean age of samples ITL 151 and Beta-29902) and before $600 \pm 100$ yr (ITL 169). This 200year age discrepancy could be explained if unit $8 \mathrm{~A}$ initially buried soil S3 in a topographic low in the western part of the graben at about 815 years B.P., and slowly accreted laterally and vertically, burying soil S3 at the toe of the scarp (at a slightly higher elevation) some 200 years later.

The inception of soil S3 formation can be estimated based on its surface age and accumulation rates of cumulic soils dated elsewhere by closely spaced vertical TL and ${ }^{14} \mathrm{C}$ dating. Forman et al. [1991] and Warren and McCalpin [1992] suggest that at distances of 5-10 $\mathrm{m}$ from the main fault, cumulic A horizons on wash facies colluvium (in semi arid climates with sagebrush vegetation) accumulate at rates of about $3 \pm 1 \mathrm{~cm} / 100 \mathrm{yr}$ between faulting events. The 63 - 
TABLE 3. Equivalent Doses and TL Age Estimates for Sediments from the 1988 Kaysville Trench, Weber Segment, Wasatch Fault Zone.

\begin{tabular}{|c|c|c|c|c|c|}
\hline $\begin{array}{l}\text { Laboratory } \\
\text { Number }\end{array}$ & $\begin{array}{l}\text { Depositional } \\
\text { Environment }\end{array}$ & Method 1 & $\begin{array}{l}\text { Temperature } \\
\text { Range, }\left({ }^{\circ} \mathrm{C}\right)^{2}\end{array}$ & $\begin{array}{l}\text { Equivalent } \\
\text { Dose, (Gy) }\end{array}$ & $\begin{array}{c}\mathrm{TL} \text { Age } \\
\text { 3Estimate, (ka)4 }\end{array}$ \\
\hline$\overline{\mathrm{TL}-149}$ & buried soil A horizon & $\begin{array}{l}\text { regeneration } 16 \text { hour SL } \\
\text { total bleach } 16 \text { hour SL } \\
\text { total bleach } 8 \mathrm{~h} \mathrm{UN} \\
\text { partial bleach } 2 \text { hour SL }\end{array}$ & $\begin{array}{l}250-350 \\
250-350 \\
250-350 \\
250-320\end{array}$ & $\begin{array}{r}9.79 \pm 3.19 \\
10.27 \pm 1.82 \\
10.29 \pm 1.01 \\
5.24 \pm 1.18\end{array}$ & $\begin{array}{l}1.6 \pm 0.2 \\
1.6 \pm 0.2 \\
1.6 \pm 0.2 \\
0.8 \pm 0.2\end{array}$ \\
\hline $\mathrm{mL}-150$ & buried soil A horizon & $\begin{array}{l}\text { total bleach } 16 \text { hour SL } \\
\text { total bleach } 8 \text { h UN } \\
\text { partial bleach } 2 \text { hour SL }\end{array}$ & $\begin{array}{l}250-350 \\
250-350 \\
250-330\end{array}$ & $\begin{array}{l}40.28 \pm 4.84 \\
42.20 \pm 4.05 \\
43.33 \pm 5.26\end{array}$ & $\begin{array}{l}6.5 \pm 0.7 \\
6.8 \pm 0.7 \\
7.0 \pm 0.9\end{array}$ \\
\hline ITL-151 & buried soil A horizon & $\begin{array}{l}\text { total bleach } 16 \text { hour SL } \\
\text { partial bleach } 1 \text { hour SL } \\
\text { total bleach } 16 \text { hour SL } \\
\text { partial bleach } 2 \text { hour SL }\end{array}$ & $\begin{array}{l}250-400 \\
250-400 \\
250-350 \\
250-320\end{array}$ & $\begin{aligned} 4.37 & \pm 0.45 \\
3.95 & \pm 0.95 \\
104.60 & \pm 12.85 \\
102.62 & \pm 14.44\end{aligned}$ & $\begin{array}{r}0.8 \pm 0.1 \\
0.7 \pm 0.2 \\
14.3 \pm 2.0 \\
14.0 \pm 2.0\end{array}$ \\
\hline ITL-153 & fluvial/lacustrine & $\begin{array}{l}\text { total bleach } 16 \text { hour SL } \\
\text { partial bleach } 2 \text { hour SL }\end{array}$ & & $\begin{array}{l}161.22 \pm 27.6 \\
203.38 \pm 41.3\end{array}$ & $\begin{array}{l}28 \pm 5 \\
35 \pm 7\end{array}$ \\
\hline$\pi L-168$ & fluvial/lacustrine & $\begin{array}{l}\text { total bleach } 16 \text { hour SL } \\
\text { partial bleach } 2 \text { hour SL } \\
\text { partial bleach } 10 \text { hour SL/OF } \\
\text { partial bleach } 14 \text { hour UV/OF }\end{array}$ & $\begin{array}{l}250-350 \\
250-320 \\
250-320 \\
250-320\end{array}$ & $\begin{array}{r}92.71 \pm 8.34 \\
97.74 \pm 13.14 \\
122.60 \pm 18.82 \\
107.00 \pm 19.76\end{array}$ & $\begin{array}{l}16 \pm 2 \\
17 \pm 3 \\
22 \pm 3 \\
19 \pm 3\end{array}$ \\
\hline IL-169 & shallow lacustrine & $\begin{array}{l}\text { total bleach } 16 \text { hour SL } \\
\text { partial bleach } 1 \text { hour SL. }\end{array}$ & $\begin{array}{l}250-370 \\
250-320\end{array}$ & $\begin{array}{l}9.55 \pm 0.87 \\
4.32 \pm 0.90\end{array}$ & $\begin{array}{l}1.2 \pm 0.2 \\
0.6 \pm 0.1\end{array}$ \\
\hline ITL-170 & shallow lacustrine & $\begin{array}{l}\text { total bleach } 16 \text { hour SL } \\
\text { partial bleach } 2 \text { hour SL }\end{array}$ & $\begin{array}{l}250-350 \\
250-350\end{array}$ & $\begin{array}{r}13.68 \pm 0.96 \\
13.12 \pm 1.43\end{array}$ & $\begin{array}{l}2.0 \pm 0.2 \\
1.9 \pm 0.2\end{array}$ \\
\hline TL-171 & buried soil A horizon & $\begin{array}{l}\text { total bleach } 16 \text { hour SL } \\
\text { partial bleach } 2 \text { hour SL }\end{array}$ & $\begin{array}{l}250-350 \\
250-350\end{array}$ & $\begin{array}{l}30.78 \pm 4.64 \\
29.27 \pm 6.95\end{array}$ & $\begin{array}{l}5.0 \pm 0.7 \\
4.7 \pm 0.9\end{array}$ \\
\hline$m-172$ & fluvial/lacustrine & $\begin{array}{l}\text { total bleach } 16 \text { hour SL } \\
\text { partial bleach } 2 \text { hour SL }\end{array}$ & $\begin{array}{l}250-350 \\
250-350\end{array}$ & $\begin{array}{l}158.20 \pm 20.51 \\
207.41 \pm 31.62\end{array}$ & $\begin{array}{l}24 \pm 4 \\
32 \pm 5\end{array}$ \\
\hline
\end{tabular}

1Hours of light exposure to define residual level. SL is natural sunlight in Boulder, Colorado. UV is light from a "General Electric" $275 \mathrm{~W}$ ultraviolet sunlamp bulb. OF is a light exposure with wavelengths below $540 \mathrm{~nm}$ blocked (<1\% transmission) with a Corning CS3-67 glass filter.

2All thermoluminescence measurements were made with a Schott UG-1 1and HA-3 filters in front of the photomultiplier tube. Samples were preheated to $150^{\circ} \mathrm{C}$ for 16 hours prior to analysis.

All samples exhibited negligible anomalous fading, within analytical resolution of $\pm 10 \%$.

3Temperature range used to calculate equivalent dose.

4 All errors are at 10 and calculated by averaging the errors across the temperature range.

cm-thick soil S3 may thus represent about $2100 \pm 630$ years of soil formation, which ended by circa $600-800$ years B.P. Soil S3 may thus have begun forming by $2800 \pm 730$ yr BP (mean value of the above ages). This age range is compatible with older TL and ${ }^{14} \mathrm{C}$ age estimates for underlying soil S1 (discussed next) and with an age of 1870 $+269 /-320$ years B.P. on fissure-fill derived from soil S3 (Figure 3 and Table 2, sample Beta-38680).

The fissures displace all units except the youngest colluvial-graben fill couplet, indicating that they opened (due to hingeline "stretching"?) during the latest faulting event. Deposition of $8 \mathrm{~A}$ is dated at ca. $600-800$ years B.P., whereas the material at the bottom of the fissure dates at $\mathbf{1 8 7 0}$ $+269 /-320$ years B.P. If this basal fissure fill material fell from soil S3 during latest faulting (shortly before 600-800 years B.P.), why does it carry a ${ }^{14} \mathrm{C}$ age of circa 1900 years B.P.? The simplest explanation is that at the time of faulting, a thick vertical slice of soil S3 fell more-or-less intact into the fissure. The material that came to rest in the bottom of the crack was actually derived from the lower part of soil S3, which had begun forming by circa $2.8 \mathrm{ka}$.

Concordancy between radiocarbon and TL age estimates was also obtained for buried soil S1. Sample ITL 150 from the A horizon of soil 1 yielded TL ages of $6.5+0.7 \mathrm{ka}$ and $6.8 \pm 0.7 \mathrm{ka}$ (total bleach), and 7.0 $40.9 \mathrm{ka}$ (partial bleach), all of which are in good agreement with the radiocarbon age of $6.3 \pm 0.3 \mathrm{ka}$. A second sample from the A horizon of soil 1 yielded somewhat younger TL ages of $5.0 \pm 0.7 \mathrm{ka}$ and 4.71 $0.7 \mathrm{ka}$ by the total and partial bleach methods, respectively. The $\mathrm{TL}$ age and ${ }^{14} \mathrm{C}$ estimates indicate that soil 1 was buried by fault scarp colluvium sometime between 3.8 ka and 7.9 ka (one-sigma age range); at two sigma, all six limiting age estimates overlap in the range 5.7-6.1 ka.

The sag pond and fluvial sediment yielded TL age estimates that are often 3 to 8 times older than the concordant TL and ${ }^{14} \mathrm{C}$ ages on adjacent buried soils. The 
bedding and current structures indicate that much of the sediment in units $3,4,5$, and 6 was deposited episodically by water moving down the axis of the graben (Table 1). Such rapidly deposited sediments probably received limited light exposure and thus contain a large inherited TL signal; TL age estimates of $16-35 \mathrm{ka}$ on sediments that must be $<13 \mathrm{ka}$ in age support this interpretation. All TL age estimates, even by the partial bleach technique, are considered overestimates on the time of deposition of these subaqueous sediments and probably reflect the age of the source materials (mainly Bonneville lake beds) from which the graben fill was derived. To date the oldest graben sediment (lithofacies 3), we calculated deposition rates in the center and western end of the graben based on a concordant series of five TL and four radiocarbon ages (Figure 4).

Extrapolation of deposition rates to the level of the 1978 radiocarbon sample suggests an age of circa 8.5 to $10.4 \mathrm{ka}$ for unit $3 b$, although deposition rates might not have been the same in the sag pond/fluvial units as in the dated distal colluvial units. We suggest that the 1978 charcoal sample from unit 3b, on which the Swan et al.'s [1980] chronology was based, was actually a root that was carbonized or burned in situ, and that their $1580 \pm 150$ year B.P. age may represent the age of the land surface on which the plant was growing (probably soil S3) rather than the age of lithofacies 3.

\section{CHRONOLOGY OF FAULTING}

\section{Reconstruction of Faulting Chronology}

We combine observations on scarp-derived colluvial wedges, tilted graben deposits, soils, and unconformities between these units, to reconstruct a sequence of cross sections (Figure 5) that show the geometric evolution of the scarp-graben system. Two assumptions are implicit in this type of geometric/stratigraphic analysis. First, the laminae within pond silts and sands in the graben were initially horizontal. The upper boundaries of fine-grained units are always parallel to internal laminae in these units and are also assumed to have been horizontal, whereas the lower boundaries of fine-grained units may have had some gentle dips. Second, the initial angle of repose of proximal scarpderived colluvium should not have changed significantly through time. Thus the present surface slope of $40^{\circ}-42^{\circ}$ near the main fault zone and long-axis plunges of $30^{\circ}-35^{\circ} \mathrm{W}$ for clasts in the youngest proximal colluvium (subunit 9B, Figure 3), indicate initial bedding angles in the older lithofacies of colluvium.

Measurements on which the geometric analysis is based include dips of the upper and lower contacts of colluvial wedges and dips of clast long-axis fabrics between $33 \mathrm{~m}$ and $38 \mathrm{~m}$, and dips of graben lithofacies contacts between $12 \mathrm{~m}$ and $17 \mathrm{~m}$ (Figure 3). Five of the contacts between units in the graben (units $3 \mathrm{a} / 3 \mathrm{~d} ; 3 \mathrm{~d} / 3 \mathrm{e} ; 6 \mathrm{~A} / 7 \mathrm{~A} ; 8 \mathrm{~A} / 8 \mathrm{~B}$; and $8 \mathrm{~B} /$ surface) are defined by the upper boundary of laminated or massive silts and clays, and are presumed to have been originally horizontal. Three other contacts that define the tops of fluvial sands and gravels are presumed to have been nearly horizontal when deposited along the graben axis

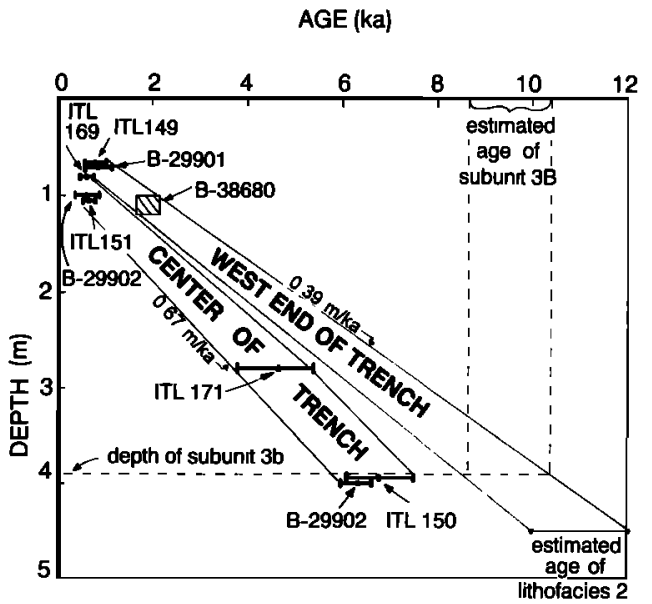

Fig. 4. Numerical ages of samples from the graben as a function of depth below the present ground surface. Sample B-38680 has been plotted at its inferred prefaulting depth (bottom of soil S3, $1.1 \mathrm{~m}$ ) rather than at its present depth at the bottom of the fissure fill $(2.5 \mathrm{~m})$. Samples from the center of the trench define a more rapid deposition rate than do samples from the west (distal) end, which is consistent with the thicker graben fill in the center of the trench. Extrapolation of age to the depth of subunit $3 b$ in the west end of the trench suggests an age of circa $8.5-10.4 \mathrm{ka}$, in contrast with the $1580 \pm 150$ year B.P. age stated by Swan et al [1980] for lithofacies 3. However, the linear extrapolation of ages below soil S1 may not be warranted, since some deposits below soil S1 (lithofacies 3 and 4) may have been deposited at different rates than the distal colluvium from which most controlling ages were derived.

(contacts between units $3 f / 4 A ; 4 A / 4 B ; 4 B / 5 A$ ). The paleo ground surfaces of two distal scarp-derived colluvial units (contacts between soil S1/6A; soil S3/8A) presumably had a slight initial valleyward gradient $\left(2^{\circ}-4^{\circ}\right.$ ?) when they became stabilized.

The following sequence of cross sections (Figure 5) reconstructs the graben geometry resulting from deposition and faulting in post-Provo time $(<13-14 \mathrm{ka})$, beginning with initial graben formation (Figure 5a) and ending with the present geometry (Figure 5i).

Stage a: Fault event(s) 1a, 1b?. The post-Provo alluvial fan (lithofacies 2) is faulted, and a graben is formed. The floor of the graben is probably tilted eastward, partially counteracting the original west slope of the alluvial fan, but the poor exposure of the unit $2 / 3$ contact precludes an exact determination of its dip. For simplicity we assign an initial $0^{\circ}$ dip to the graben floor. Displacement analysis (Table 4) suggests that one or two faulting events occurred before deposition of lithofacies 3 .

Stage $b$ : Any scarp-derived colluvium shed after fault event(s) 1 is presumably beneath the floor of the trench at its eastern end (noted by question marks). In the graben, lithofacies 3 accumulates by subaqueous deposition in a perennial pond. The variable units within lithofacies 3 


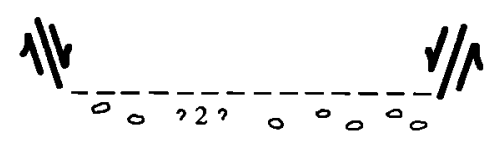

a.

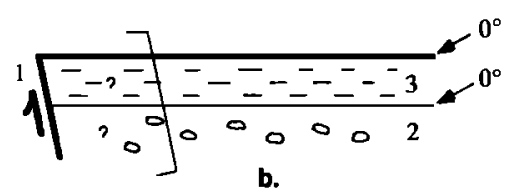

b.

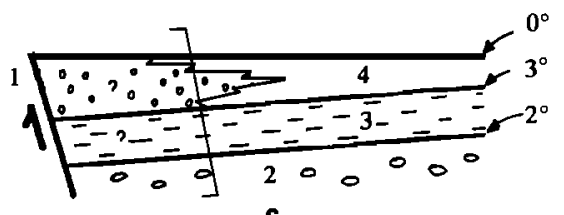

c.

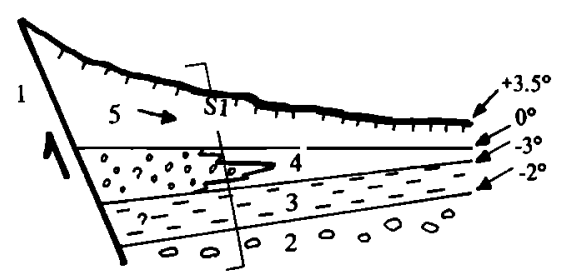

d.
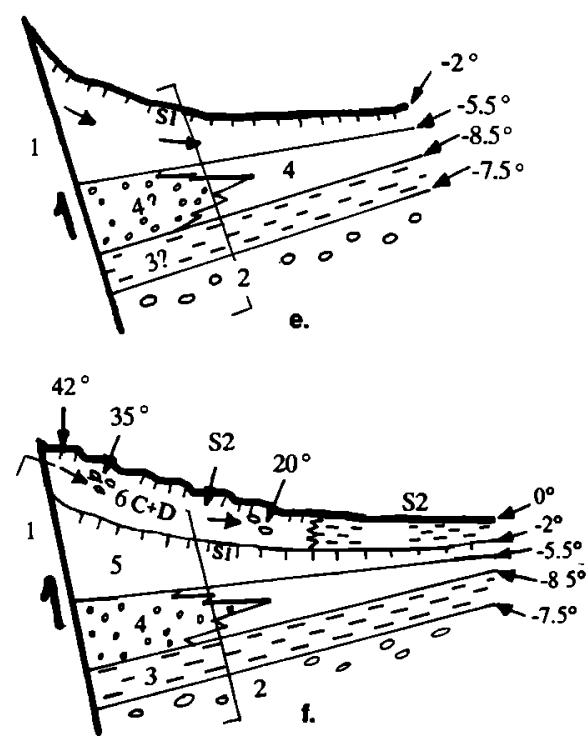
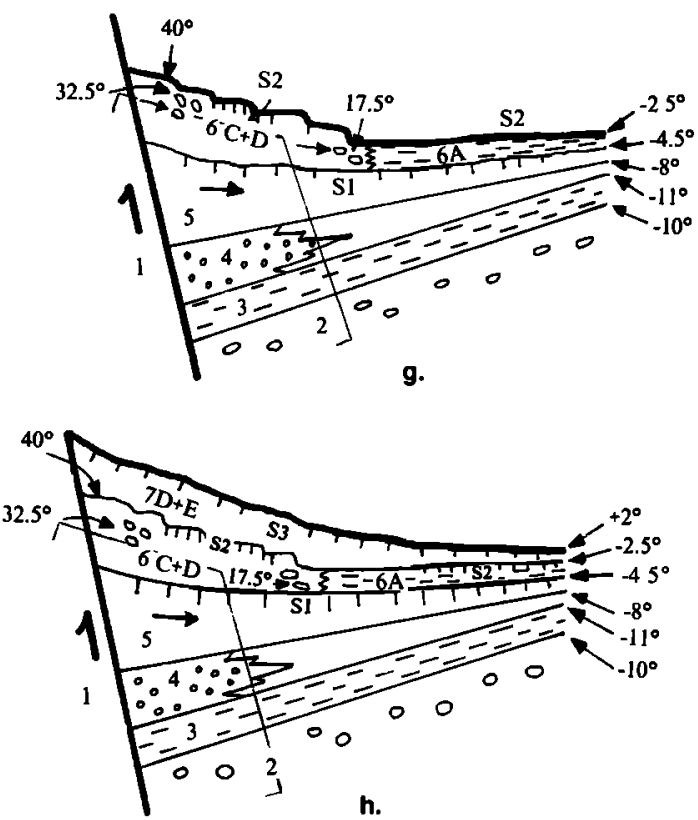

h.

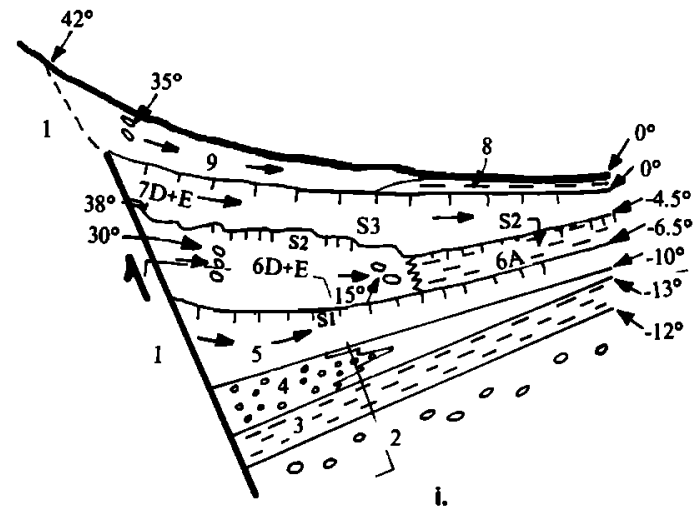

i.

Fig. 5. Sequential cross sections of the Kaysville trench showing inferred geometry that evolves through time, from stage a (initial stage) to stage h (present configuration of the trench; compare to Figure 3). See text for detailed descriptions of each stage. All features to the left of and below the bracketed line are hypothetical, because they were beneath the trench floor.

(Table 1) may correspond to pulses of faulting-induced sedimentation, but the exact correlation with scarp-derived colluvium(s) is unclear. At the end of lithofacies 3 deposition, upper laminae are horizontal. Extrapolation of a constant deposition rate implies the lower part of this unit is circa 8.5-10.2 ka (Figure 4), rather than $1.5 \mathrm{ka}$, as dated by Swan et al. [1980]. The lack of a soil beneath lithofacies 3 implies that earliest graben sedimentation began immediately after cessation of post-Provo fan deposition. Stage c: Fault event 2. Faulting tilts lithofacies 2 and 3 


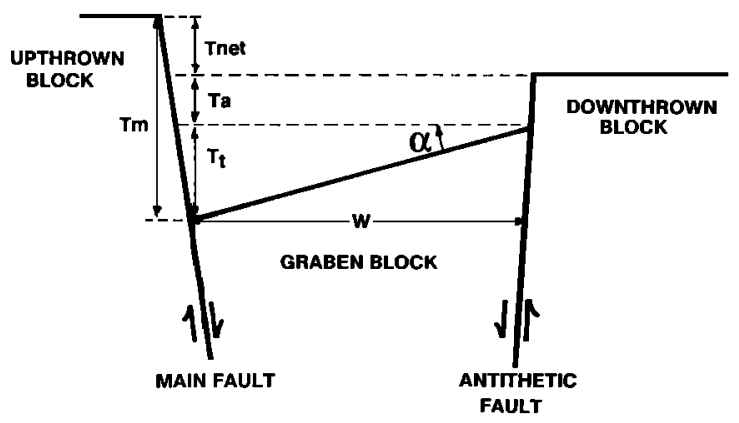

Fig. 6. Schematic diagram showing the three components of vertical fault displacement $(T)$ at a scarp with a tilted graben. For simplicity, the hingeline of graben tilt in this diagram has been made coincident with a single antithetic fault; at the Kaysville trench, the Holocene tilt hingeline is actually $9 \mathrm{~m}$ east of the main antithetic fault. Tm is the height of main fault scarp (also equals throw on main fault for horizontal offset surfaces); Ta is the height of antithetic fault scarp; $\mathrm{Tt}$ is the throw at main fault due to tilting of graben; Tnet is the net throw across fault zone; $W$ is the width of tilted graben; and alpha is the graben tilt angle.

about $2^{\circ}$ to $3^{\circ}$ eastward. A stream (Baer Creek?) is diverted into the tilted graben and deposits lithofacies 4 . The coarser gravels of unit $4 \mathrm{~A}$ (open circles) probably constitute a channel deposited near the scarp toe, of which only the most distal part is exposed in the trench. How these channel gravels interfinger with early scarp-derived colluvium (basal part of unit 5) is unknown. Fluvial deposition in the western part of the graben continued and eventually created a nearly horizontal ground surface (upper contact of lithofacies 4).

Stage d: The scarp-derived colluvial wedge (lithofacies 5) continues to grow valleyward, and wash-facies colluvium builds out westward over lithofacies 4 . As deposition slows, a cumulic A horizon (soil S1) forms on the colluvial wedge. Soil S1 cannot be differentiated as a separate unit west of meter 11 (Figure 3), because unit 5 becomes uniformly organic.

Stage e: Fault event 3. Faulting tilts all graben units $5.5^{\circ}$ eastward. Tilting rotates the top contact of lithofacies 4 from horizontal to $-5.5^{\circ}$ (east) and reverses the local slope on the top of (distal) soil S1 (right side of diagram) from $3.5^{\circ}$ (west) to $-2^{\circ}$ (east).

Stage $f$ : Post faulting sediments bury the top of soil S1 from two directions. Near the main fault, subunits $6 \mathrm{C}$ and $6 \mathrm{D}$ are deposited as a westward growing wedge of proximal colluvium on the earlier lithofacies 5 wedge. By $47.9 \mathrm{ka}$, the wedge had advanced $10 \mathrm{~m}$ west of the fault and buried soil S1. Clasts in the proximal colluvium (6C and $6 \mathrm{D}$ ) have reconstructed long-axis plunges of $30^{\circ}-40^{\circ}$ west, whereas farther west plunges decrease to $20^{\circ}$. Contemporaneous with proximal wedge deposition, a pond forms in the graben on the back tilted soil $S 1$ surface (which now dips $2^{\circ} \mathrm{E}$ ) and clayey silts are deposited (unit 6A). After the fault free face is destroyed by slope retreat, the rate of deposition on the colluvial slope decreases. Organic matter accumulates, and a thin cumulic soil (S2) forms.

Stage $g$ : Fault event 4 . This event tilts the graben sequence eastward by another $2.5^{\circ}$. This tilt rotates the originally horizontal top of subunit $6 \mathrm{~A}$ to $2.5^{\circ}$ (east) and rotates all other underlying graben units to near their present dip. Near the fault zone, the upper and lower contacts of proximal colluvial wedges and clast fabrics are likewise rotated $2.5^{\circ}$ eastward, which decreases their previous westward orientations.

Stage $h$ : Scarp-derived colluvium shed from free face(s) of event 4 comprises units 7D and 7E. Clasts in the subunit 7E colluvial wedge have reconstructed long-axis plunges of $35^{\circ}$ west near the fault. Soil S3 developed on wash facies colluvium (7A and $7 B$ ), possibly beginning by 2.1-3.5 ka. The distal surface of stabilized soil $\$ 3$ is assigned a reconstructed gradient of $2^{\circ}$ (west), based on the minimum gradient observed in modern distal colluvium (unit 9B).

Stage $i$ : Fault event 5 . Soil S3 is displaced by faults at $35 \mathrm{~m}$ and $36 \mathrm{~m}$ on the $\log$ (Figure 2). The graben tilts approximately $2^{\circ}$ eastward, bringing the surface of S3 to horizontal and all underlying units to their present dips. The hingeline region for this eastward tilt, between $5 \mathrm{~m}$ and 11 $\mathrm{m}$ on Figure 3, is stretched and responds by forming large tension fissures. A sliver of soil S3 falls into these cracks (sample Beta-38680). Lithofacies 9 (proximal colluvium) is shed from free faces over faults at $35 \mathrm{~m}$ and $36 \mathrm{~m}$ on the $\log$ and buries soil S3. The newly depressed graben surface traps more pond sediment (lithofacies 8). The basal part of lithofacies 8 buries soil S3 circa 800 years B.P. The distal part of lithofacies 9 overrides those parts of lithofacies 8 closest to the base of the scarp, eventually covering even historic deposits (unit 8B) in the graben.

Our preferred scenario based on the preceding reconstruction contains four faulting events recognized from colluvial wedges and evidence of tilting in the graben (fault events 2, 3, 4, 5, Figure 5), with an additional 1-2 (?) faulting events suggested by total height of the scarp and depth of the graben (fault events 1a, 1b; Figure 5). All (five or six) faulting events postdate the post-Provo alluvial fan (age $\leq 13 \mathrm{ka}$ ).

\section{Displacements in Individual Paleoevents}

Displacements in individual paleoevents at Kaysville can be estimated from deposit geometry exposed in the trench. The three geometric components of fault displacement in this scarp-graben system are (1) stratigraphic throw at the main fault zone (Tm, approximately equal to initial height of the scarp free face), (2) eastward tilt ( $\alpha$ ) of the graben strata acting over a certain horizontal distance (W) from the main fault, and (3) stratigraphic throw on any antithetic faults (Ta; Figure 6). If all three components are known for an individual faulting event, the net coseismic throw (Tnet) for that event is measured as the difference between main fault throw, and contributions of throw from tilt $(T \approx W \tan \alpha)$ and antithetic faulting (Figure 6). This relation is summarized by

$$
\text { Tnet }=\mathbf{T m}-[(\mathbf{W} \tan \alpha)+\mathbf{T a}]
$$


Tm for each of the seven or eight paleoseismic events at Kaysville cannot be measured directly, because no correlative interfaulting strata are preserved on both sides of the main fault. However, diffusion modeling of fault scarp decline [Nash, 1980] predicts that over time the maximum thickness of scarp-derived colluvium approaches $50 \%$ of initial scarp height. Previous workers [Ostenaa, 1984] have suggested that subject to some limitations, maximum colluvial thickness could be multiplied by 2 to approximate the height of individual paleo-scarps (and thus Tm). We adopt this technique and estimate $\mathbf{T m}$ for each paleoevent by multiplying maximum colluvial thickness by an appropriate factor (Table 4, columns 2 and 3 ).

The eastward tilt of the graben during the last four paleoevents is estimated from angular unconformities in the graben fill (Figure 5). These tilts have acted over an estimated horizontal distance of $33 \mathrm{~m}$ (W in Figure 6, the distance from the Holocene hingeline to the main fault in Figure 3), allowing us to calculate $T_{t}$. Throw on the main antithetic fault (which is beyond the western end of the 1988

TABLE 4. Fault Displacement at the Kaysville Trench Site

\begin{tabular}{|c|c|c|c|c|c|c|c|}
\hline \multirow[t]{2}{*}{$\begin{array}{l}\text { Parameter } \\
\text { Measured }\end{array}$} & \multirow[t]{2}{*}{$\begin{array}{l}\text { Faulting } \\
\text { Event: }\end{array}$} & \multirow{2}{*}{$\begin{array}{l}\text { Maximum } \\
\text { Colluvial } \\
\text { Thickness } \\
\text { m }\end{array}$} & \multicolumn{4}{|c|}{$\begin{array}{c}\text { Vertical } \\
\text { Displacements, m }\end{array}$} & \multirow[t]{2}{*}{$\begin{array}{l}\text { CNVTD, } 5 \\
\text { m }\end{array}$} \\
\hline & & & $\begin{array}{l}\text { Main } \\
\text { Fault }\end{array}$ & $\begin{array}{l}\text { Other } \\
\text { Syn- } \\
\text { thetic } \\
\text { Faults } \\
\end{array}$ & T11t ${ }^{3}$ & $\begin{array}{l}\text { Antithetic } \\
\text { Faults }\end{array}$ & \\
\hline \multirow{3}{*}{$\begin{array}{l}\text { Displace- } \\
\text { ment per } \\
\text { faulting } \\
\text { event }\end{array}$} & \#5 & $1.3^{6}$ & $3.5^{\prime}$ & 0.5 & $\begin{array}{l}\text { none or } \\
1.2^{8}\end{array}$ & $\begin{array}{l}2.1 \text { or } \\
1.1^{9}\end{array}$ & $1.7-1.9$ \\
\hline & $\# 4$ & 2.4 & $4.8^{10}$ & 0 & $1.4^{11}$ & $\frac{1}{0^{12}} 1$ or & $2.3-3.4$ \\
\hline & \#3 & $2.3^{13}$ & $4.6^{14}$ & 0 & $3.2^{15}$ & 0 & 1.4 \\
\hline \multicolumn{2}{|c|}{$\begin{array}{l}\text { Total thickness or } \\
\text { displacement in latest } \\
3 \text { events }(t) \text { and mean } \\
(t / 3)\end{array}$} & $6.0 / 2.0$ & $12.9 / 4.3$ & 0.5 & & $6.8-8.0$ & $\begin{array}{l}4.9-6.11 \\
1.6-2.0\end{array}$ \\
\hline \multicolumn{2}{|c|}{$\begin{array}{l}\text { Total displacement } \\
\text { across entire zone of } \\
\text { deformation }(\mathrm{T})\end{array}$} & $\geq 11.0^{16}$ & $\geq 25.0^{17}$ & & & & $10.0-11.0^{10}$ \\
\hline \multicolumn{2}{|c|}{$\begin{array}{l}\text { Residual between total } \\
\text { displacement ( } T \text { ) and } \\
\text { displacement in latest } \\
3 \text { events ( } t)\end{array}$} & $\geq 5.0$ & $\geq 12.1$ & & & & $3.9-6.1$ \\
\hline \multicolumn{2}{|c|}{$\begin{array}{l}\text { Number of average- } \\
\text { displacement events } \\
\text { needed to account for } \\
\text { the residual } \\
\text { displecement }\end{array}$} & $\begin{array}{l}2-3 \\
\text { events }\end{array}$ & 3 events & & & & $\begin{array}{l}2-3 \\
\text { events }\end{array}$ \\
\hline
\end{tabular}

Data are from this paper ans Swan et al., 1980

1 Numbers refer to faulting events defined in text.

2 Throw on the main fault zone, measured as stratigraphic offset, or inferred from thickness of colluvial wedges. See individual footnotes for methods of calculation.

3 Calculated as the product of the width of the tilted part of the graben (33 m) times the tangent of backtilting angles for each faulting event (from Figure 5).

4 Throw on the two major antithetic faults, measured from stratigraphic offsets in the 1978 trench [Swan

set al 1980 , p. 1441 J. individual events by subtracting antithetic or tilt-induced displacement from stratigraphic displecement

- From Swan et al. [1980], $\log$ of Trench A; maximum thickness in the 1988 trench was only $0.8 \mathrm{~m}$, but was

truncated by excavation. [1981, p. 23] as the vertical distance between the base of the youngest colluvial wedge and the lower infiection point on the main scarp. If accurate, this value suggests the maximum colluvial thickness was only $37 \pi$ of free face height.

west gradient. $2.1 \mathrm{~m}$ if all antithetic displacement occurred in the latest event, as stated by Swan et al. [1980]; $1.1 \mathrm{~m}$ if antithetic displacement is divided evenly between the two latest faulting events.

1. Assuming maximum colluvial thickness was $50 z$ of free face height

11 Arc of $2.5^{\circ}$ backtilt over $33 \mathrm{~m}$ distance (see footnote 3 for method of calculation)

$121.1 \mathrm{~m}$ if half of antithetic displacement occurred in penultimate event; $0 \mathrm{~m}$ if all antithetic

13 value is based on projection, assuming that lithofacies 6 was deposited on an underlying colluvial slope

identical in longitudinal profile with its own upper surface, but backtilted $2^{\circ}$ more. Maximum observed

thickness is $1.8 \mathrm{~m}$.
14 Assumed to be twice the maximum colluvial thickness.

15 Arc of a $5.5^{\circ}$ backtilt over a $33 \mathrm{~m} \mathrm{distance} \mathrm{(see} \mathrm{footnote} 3$ for method of calculation).

16 Measured by projecting the surface of post Provo fan (lithofacies 2/3 contact, Figure 2) from its

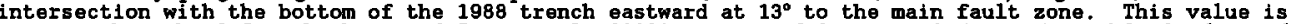
greater than the $8.5 \mathrm{~m}$ thickness of Swan et al. [1980, Figure 4] because their projected backtilt angle was only $5^{\circ}-6^{\circ}$. The $11 \mathrm{~m}$ value is a minimum because it assumes (1) backtilt does not keep increasing toward the fault, and (2) there are no buried antithetic faults beneath the trench floor.

Stratigraphic separation of the contact between Bonneville lacustrine deposits and post-Provo alluvial fan across the main fault zone (as projected by Swan and others, 1981, p. 23). Because their projectlon assuned a maximum backtilting angle of $5^{\circ}-6^{\circ}$, instead of the $13^{\circ}$ observed in the 1988 trench, the value

cited hrom Swen et al. [1981, p. 22]; measured by projecting the modern ground surface across the zone of deformation (same as vertical surface offset). 
trench) was measured by Swan et al. [1981] at $2.2 \mathrm{~m}$, based on stratigraphic separations of graben fill units. Using equation (1), we show our estimates of the net throw for each of the last three surface-rupturing events in Table 4.

The net throw across the entire deformation zone is estimated at $1.4 \mathrm{~m}$ for fault event $3,2.3-3.4 \mathrm{~m}$ for fault event 4, and 1.7-1.9 m for fault event 5. Only about $50 \%$ of the total displacement across the main fault, or of net displacement across the graben, or of colluvial thickness, can be accounted for by the three latest paleoevents (Table 4, row 2). Assuming that paleoearthquake displacements have been similar through time (characteristic behavior as defined by Schwartz and Coppersmith [1984]), another two or three paleoevents may have occurred $(1 \mathrm{a}, 1 \mathrm{~b}$, and 2$)$, the colluvial wedges of which are buried beneath the trench floor.

Slip Rates, Recurrence Intervals, and Paleomagnitude Estimates

The post-Provo $(<13 \mathrm{ka}$ ) slip rate at Kaysville was calculated by Swan et al. [1980] as $1.8(+1.0 /-0.6) \mathrm{mm} / \mathrm{yr}$, based on a net $10-11 \mathrm{~m}$ of vertical displacement of the postProvo alluvial fan, the age of which they estimated to be circa $₫ \mathbb{2} \mathrm{ka}$. The improved numerical age control from this study suggests the alluvial fan is considerably older, probably in the range 10-12 ka; these new values indicate a long-term (circa $12 \mathrm{ka}$ to present) slip rate of $0.8-1.1 \mathrm{~mm} / \mathrm{yr}$. The midlate Holocene slip rate defined by events 3,4 , and 5 , calculated from displacement estimates in Table 4, ranges from $0.7-1.7 \mathrm{~mm} / \mathrm{yr}$ to $0.9-1.2 \mathrm{~mm} / \mathrm{yr}$, depending on the maximum age assumed for soil S1 (7.9 ka versus $6.1 \mathrm{ka}$ ). These new values are only $50-70 \%$ of the rate calculated by Swan et al. [1980] but compare well with Holocene slip rates from other Holocene segments of the WFZ which range from 0.5-1.5 mm/yr [Machette et al., 1992, Figure 21].

Recurrence intervals can be calculated based on estimated ages for the three events of $0.6-0.8 \mathrm{ka}, 2.8 \pm 0.7 \mathrm{ka}$, and 3.8$7.9 \mathrm{ka}$ (preferred range of 5.7-6.1 ka). The time interval between events 3 and 4 ranges from 0.5-6.2 $\mathrm{ka}$ if the broadest age range is used, to $2.2-4.2 \mathrm{ka}$ if the smaller (preferred) age range is used. For events 4 and 5, time intervals calculated the same way are $1.1 \mathrm{ka}$ and $2.7 \mathrm{ka}$, respectively. The composite recurrence interval for events 3 , 4 , and 5 is $3.6 \mathrm{ka}$ (based on two intervals in the span 0.8-7.9 ka) or $2.7 \mathrm{ka}$ (based on two intervals in the span 0.8-6.1 ka). The composite recurrence interval for post-Provo time $(\leq 13$ $\mathrm{ka}$ ), assuming five or six paleoearthquakes, is $2.2-2.6 \mathrm{ka}$. According to the graphical reconstruction of fault timing (Figure 7), the recurrence interval between events early in the Holocene (1a, 1b, 2) must have been considerably shorter than intervals since circa 6 ka.

The magnitudes of paleoearthquakes 3,4 , and 5 can be inferred from net displacement (Table 4) compared to historic magnitude-maximum displacement relations. According to the normal fault data of Bonilla et al. [1984] our inferred displacements suggest $M_{s} 6.9$ for event 3, $M_{s}$ 7.2 for event 4 , and $M_{s} 7.0$ for event 5 . These magnitude estimates are minima, because the displacement observed at the Kaysville site may not have been the maximum produced in each event.

\section{COMPARISON OF CHRONOLOGIES AT KAYSVILLE AND EAST OGDEN}

The revised Kaysville chronology can be compared to the paleoseismic chronology deduced by Nelson [1988], Forman

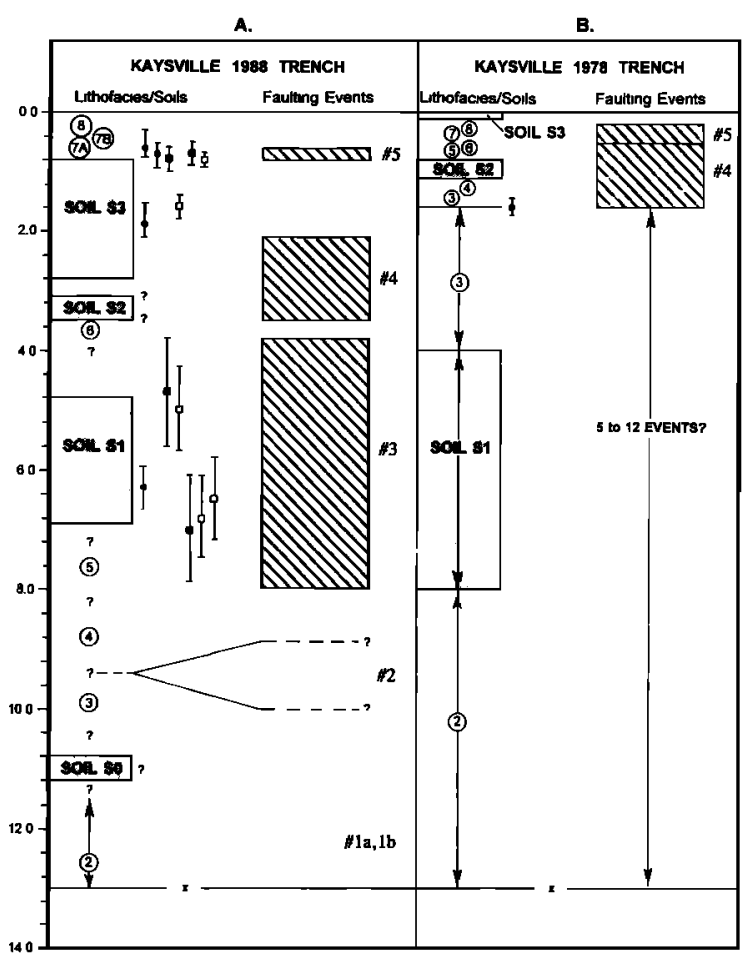

Figure 7. Diagrams contrasting the stratigraphic chronology and age of inferred faulting events as interpreted in this paper (A) and in Swan et al. [1980] (B). Circled numbers show lithofacies units as defined in this paper. Soil numbers in column $A$ refer to this paper, and in column B are as defined by Swan et al. [1980]. Soil S3 is the same soil in both columns; column B soil S2 is the same as column A soil S1, because Swan et al. did not recognize our soil S2. Soil S1 in column B is the same as soil S0 in column A. Soil S1 of Swan et al. [1980] was not observed in the 1988 trench. Because this soil should underlie lithofacies 3, it must have developed prior to 8.5$10 \mathrm{ka}$. We schematically show this soil as our soil S0, the age limits of which are queried. Black squares indicate TL age estimates, black circles show radiocarbon ages. Faulting events (right side of each column, numbered as in text) are inferred to have occurred during time spans in diagonal ruled boxes, with X's showing preferred age ranges, as limited by numerical ages on the left side of each column. We show when our events 4 and 5 would have to have occurred in the Swan et al. [1980] chronology (column B). Question marks indicate uncertainty in limiting ages. 
et al. [1991], and Machette et al. [1992] at the East Ogden, Utah, site on the Weber segment of the WFZ $25 \mathrm{~km}$ north of the Kaysville site. The three latest events at East Ogden were dated by ${ }^{14} \mathrm{C}$ and TL techniques [Forman et al., 1991; Machette et al., 1992] at 0.8-1.2 ka, 2.5-3.0 ka, and 3.5-4.0 ka. In a simple statistical test of the respective limiting ages (Table 5) outlined below, we can test whether the latest three events at each site are likely to have been the same. Ages in Table 5 represent either (1) soil horizons buried by colluvium or (2) the basal parts of colluvium or graben fill that accumulated soon after the faulting event. Most dated samples were buried by scarp-derived colluvium within 3-5 $m$ of the free face. Studies on historical normal fault scarps [Wallace, 1980, 1984; Crone et al., 1987] show that proximal colluvium can prograde out 3-5 m from the free face in 5-70 years. In this analysis we assume that the dated soils under proximal colluvium were buried within 100 years of faulting. Samples from distal colluvium (includes many of the TL age estimates) and graben fill may have been deposited considerably after the faulting event, depending on distance from the scarp and local sedimentation rates and patterns. We include only the most closely limiting distal colluvium ages in Table 5, which we assume date from within circa 200-300 years of the causative event.

Two suites of ages can be considered the same if the absolute difference between the mean of the two suites is less than some number (usually two) of standard deviations
[Geyh and Schleicher, 1990]. Different types of age estimates $\left({ }^{14} \mathrm{C}\right.$, TL total bleach, and TL partial bleach) should not be mixed into a single suite, because they may all relate to slightly different time scales. Ages can be considered the same if

$$
\mathrm{t}_{1}-\mathrm{t}_{2} \leq \mathrm{k} \text { sigma }(\mathrm{t} 1-\mathrm{t} 2)
$$

where: $t_{1}$ is mean ages from one site, $t_{2}$ is mean ages from another site, $\mathbf{k}$ is the number of standard deviations to consider (typically 2 for geochronological comparisons), and sigma (t1-t2) is the standard deviation of $t_{1}-t_{2}$.

Subtraction of ages follows the rule that

$$
t_{1}-t_{2}=t_{1}-t_{2} \pm \sqrt{\left(\text { sigma }_{1}\right)^{2}+\left(\text { sigma }_{2}^{2}\right)}
$$

Applying (2) to the ages in Table 5, we conclude the following. The latest faulting event at the Kaysville and East Ogden sites was the same, based on ${ }^{14} \mathrm{C}$ ages (see example calculation in Table 5) and total-bleach TL ages. Partialbleach ages contradict this conclusion but those age estimates also carried the highest analytical uncertainties, and are considered the least reliable. The penultimate faulting event, based on comparison of ${ }^{14} \mathrm{C}$ ages only, was also the same at both sites. This conclusion is admittedly weak, because it is supported by a single age estimate

\begin{tabular}{|c|c|c|c|c|c|c|}
\hline & \multicolumn{2}{|l|}{ Kaysville } & \multicolumn{3}{|c|}{ East Ogden } & \multirow[b]{2}{*}{ Partial Bleach ${ }^{4}$} \\
\hline & ${ }^{14} \mathrm{C}^{2}$ & Total Bleach ${ }^{3}$ & Partial Bleach $^{4}$ & ${ }^{14} C^{2}$ & Total Bleach $^{3}$ & \\
\hline $\begin{array}{l}\text { Latest event } \\
\text { (event 5) } \\
\text { Mean }\end{array}$ & $\begin{array}{l}600+180 /-272 \\
737+243 /-187 \\
669 \pm 156\end{array}$ & $\begin{array}{l}800+100 \\
1600+200 \\
1200+112\end{array}$ & $\begin{array}{l}700+200 \\
800+200 \\
750 \pm 141\end{array}$ & $\begin{array}{l}688+258 /-148 \\
966+304 /-236 \\
827+169\end{array}$ & $\begin{array}{l}1200+100 \\
1200+200 \\
1500+200 \\
1300+100\end{array}$ & $\begin{array}{l}1400 \pm 200 \\
\text { not done } \\
1900 \pm 400 \\
1650+223\end{array}$ \\
\hline $\begin{array}{l}\text { Penultimate } \\
\text { event (event 4) }\end{array}$ & $2800 \pm 730$ & & & $3211+358 /-442$ & $3200 \pm 300$ & $3800 \pm 400$ \\
\hline $\begin{array}{l}\text { Earliest } \\
\text { event (event 3) }\end{array}$ & $6297+326 /-348$ & $\begin{array}{l}5000 \pm 700 \\
6500 \pm 700 \\
6800 \pm 700\end{array}$ & $\begin{array}{l}4700 \pm 900 \\
7000 \pm 900 \\
5850 \pm 636\end{array}$ & $\begin{array}{l}4606+253 /-197 \\
4746+467 /-327 \\
4676+228\end{array}$ & $\begin{array}{l}4000 \pm 400 \\
4600 \pm 400 \\
4300 \pm 282\end{array}$ & $\begin{array}{l}3900 \pm 600 \\
4600 \pm 500 \\
4250 \pm 390\end{array}$ \\
\hline Mean & & $6100 \pm 404$ & & & & \\
\hline
\end{tabular}

TABLE 5. Comparison of Numerical Ages That Closely Limit Faulting Events at Kaysville and East Ogden, Utah.

\footnotetext{
${ }^{1}$ Boldface indicates mean ages from each age subgroup. The mean values substituted into equation 5 constitute a test of contemporaneity. For example, for the latest event, ${ }^{14} \mathrm{C}$ ages only: $\mathrm{t}_{\text {east }}$ Ogden $-\mathrm{t}_{\text {Kaysville }}=(827 \pm 169$ years B.P. $)-(669 \pm 156$ years B.P.) $=158$ years $\pm \sqrt{169^{2}+156^{2}}=158+230$ years. By equation $(2), 158$ years $\leq 2$ (230 years), therefore events are the same.

${ }^{2}$ Radiocarbon ages; all values are in calendar-corrected years, uncertainty is $1 \sigma$.

3 Thermoluminescence age estimates by the total-bleach method; values in years on "Thermoluminescence time scale", uncertainty is $1 \sigma$.

${ }^{4}$ Thermoluminescence age estimates by the partial bleach method; values in years on "Thermoluminescence time scale", uncertainty is $1 \sigma$.
} 
(based on soil accumulation rates) at Kaysville. For the earliest faulting event, all suites of age estimates at the two sites $\left({ }^{14} \mathrm{C}\right.$ and $\left.\mathrm{TL}\right)$ fail the test of contemporaneity; therefore we conclude that these events could not have been the same.

The age comparison above implies that the 3.5-4.0 ka surface rupture at East Ogden died out before reaching the Kaysville site, $25 \mathrm{~km}$ to the south. The earliest event at Kaysville (5.7-6.1 ka?), in contrast, was probably too old to have been detected at East Ogden, where trenches were excavated in a mid-Holocene fan circa $5 \mathrm{ka}$. Due to the limited scope of our investigation, we are unable to explain exactly why a surface rupture with over $5 \mathrm{~m}$ vertical displacement at East Ogden would die out within the Weber segment. One possibility is that a subsegment boundary exists between the two sites. For example, Machette et al. [1987] suggested that the Provo segment (at $69 \mathrm{~km}$ the longest segment of the WFZ) was composed of subsegments, although more recent studies have modified that view [Machette et al., 1992]. In the latest segmentation analysis of the WFZ, Wu (1993) proposes that the Weber segment is composed of two subsegments, termed the Ogden (northern) and Bountiful (southern) subsegments, with the boundary at Weber Canyon. This subsegment boundary was defined on the basis of a large-scale wavelength analysis of fault scarps, so it lacks the multiple geological and geophysical anomalies associated with the other major segment boundaries of the WFZ [Wheeler and Krystinik, 1992]. Variations in fault scarp height along strike also permit the possibility of some kind of discontinuity at Weber Canyon [Nelson and Personius, 1990, Figure 2]. A subsegment boundary at Weber Canyon thus currently provides the most reasonable explanation for the diachroneity of earliest events at the two well-dated trench sites.

A final difference between the chronology of events at the Kaysville and East Ogden sites is the absence of evidence for a very young paleoearthquake at about 500 years B.P. at Kaysville. Such an event was postulated by Machette et al. [1992, Figure 12, event D] at East Ogden, but the evidence for the event was found in only one of five trenches and in only one of two trenches on the same fault scarp. In addition, the well-dated exposure at Garner Canyon, $5 \mathrm{~km}$ north of East Ogden, shows no evidence for a 500 -year event; the latest event there is dated at 0.8-1.2 ka. Despite the ambiguous stratigraphic evidence for a 500 -year event at East Ogden, it was considered as probable because Swan et al. [1980, 1981] had dated the latest event at Kaysville as very young, circa 500 years B.P. As we have shown in this paper, however, the latest event at Kaysville actually occurred before 0.6-0.8 $\mathrm{ka}$ and cannot be used as supporting evidence for a very young event at East Ogden. The lack of a 500-year event at either the Garner Canyon site or the Kaysville site, on either side of the East Ogden site, casts doubt on the validity of the proposed 500 - year event at East Ogden [Machette et al., 1992].

\section{CONCLUSIONS}

Detailed stratigraphic analysis and geometrical reconstructions from the 1978 and 1988 Kaysville trenches reveal evidence for five to six paleoseismic events in the past $13 \mathrm{ka}$. Our reconstructions rely heavily on the sedimentology of graben deposits and indicators of original dip angle, such as pebble orientations in colluvium. The latest three faulting events (3-5) were accompanied by net vertical displacements of 1.4 to $3.4 \mathrm{~m}$, by eastward tilting of the graben of $2^{\circ}-5.5^{\circ}$, and by antithetic faulting of $2.2 \mathrm{~m}$ per event. Evidence for the earlier two to three paleoseismic events is presumably buried beneath the trench floor.

Four radiocarbon and five TL age estimates are used to date the latest faulting event as slightly older than $0.6-0.8 \mathrm{ka}$, the penultimate event shortly before $2.8 \pm 0.7 \mathrm{ka}$, and the earliest event around 3.8-7.9 ka (preferred age range 5.7-6.1 ka). TL age estimates from buried soil A horizons are generally concordant with MRT-corrected radiocarbon ages from the same horizons, whereas TL age estimates from fine-grained sag pond silts indicate much older ages than suggested by radiocarbon ages and stratigraphy of Lake Bonneville. We infer that sag pond silts in large grabens may accumulate rapidly (Figure 2) in perennial ponds without initial "zeroing" of TL. In contrast, silts from small, intermittent sag ponds are well zeroed and yield accurate TL estimates of deposit age [Forman et al., 1989, 1991].

The two latest faulting events dated at Kaysville correlate well with the two latest events at East Ogden, $25 \mathrm{~km}$ to the north on the Weber segment. A third event recognized at East Ogden (3.4-4.0 ka) cannot be identified by any tectonic or depositional features at Kaysville. This event may have died out within the Weber segment, at a possible subsegment boundary at Weber Canyon which lies between the two trench sites.

Acknowledgments. We thank Ray Harvey of Fruit Heights, Utah, for allowing trenching on his property and the County Commissioners of Davis County, Utah, for providing excavating equipment and personnel. The Utah Geological and Mineral Survey provided hydraulic trench shores. D. P. Schwartz contributed many helpful observations about the 1978 trench and radiocarbon sample and also reviewed this paper, although he does not necessarily concur with our reevaluation of fault chronology. A. R. Nelson and M. N. Machette provided critical reviews and editorial comments on this paper. D. Wu provided unpublished data on the segmentation of the Weber segment. S. P. Nishenko showed J.P.M. how to test suites of radiocarbon ages for contemporaneity. This research was supported by U.S. Geological Survey contract 14-08-0001-G1396.

\section{REFERENCES}

Blair, T. C. and W.L. Bilodeau, Development of tectonic cyclothems in rift, pull-apart, and foreland basins; sedimentary response to episodic tectonism, Geology, 16, 517-520, 1988 Bonilla, M. G., R.K. Mark, and J_J. Lienkaemper, Statistical relations among earthquake magnitude, surface rupture length, and surface fault displacement, Bull. Seismol. Soc. Am. 74, 2379-2411, 1984. 
Crone, A. J., M. N. Machette, M. G. Bonilla, J. J. Lienkaemper, K. L. Pierce, W. E. Scott, and R. C. Bucknam, Surface faulting accompanying the Borah Peak earthquake and segmentation of the Lost River fault, central Idaho Bull. $_{\text {. }}$ Seismol. Soc. Am. 77, 739-770, 1987.

Currey, D. R. and G. C. Oviatt, Durations, average rates, and probable causes of Lake Bonneville expansions, stillstands, and contractions during the last deep-lake cycle, 32,000 to 10,000 years ago, in Problems of and Prospects for Predicting Great Salt Lake Levels, edited by P. A. Kay amd H. F. Diaz, pp. 9-24, Center for Public Affairs and Adminstration, University of Utah, Salt Lake City, 1985.

Forman, S. L., Application and limitations of thermoluminescence to date Quaternary sediments, Quat. Int., 1, 47-59, 1989.

Forman, S. L. and M. N. Machette, Thermoluminescence dating of terrestrial sediment, in The Geology of North America, vol. K2, Quaternary Non-Glacial Geology of the Conterminus United States, edited by $R$.

B. Morrison, pp. 61-65, Geological Society of America, 1991.

Forman, S. L., M. N. Machette, M. E. Jackson, and $\mathrm{P}$. Maat, An evaluation of thermoluminescence dating of paleoearthquakes on the American Fork segment, Wasatch fault zone, Utah, J. Geophys. Res., 94, 1622-1630, 1989.

Forman, S. L., A. R. Nelson, and J. P. McCalpin, Thermoluminescence dating of fault scarp derived colluvium: Deciphering the timing of paleoearthquakes on the Wasatch fault zone, north-central Utah, J. Geophys. Res., 96, 595-605, 1991

Geyh, A. A. and H. Schleicher, Absolute Age Determination, Springer-Verlag, New York 1990.

Hanson, K.L. and D. P. Schwartz, Guidebook to Late Pleistocene and Holocene faulting along the Wasatch Front and vicinity - Little Cottonwood Canyon to Scipio, Utah, Chapman Conference on Fault Behavior and The Earthquake Generation Process, AGU, Snowbird, Utah, Oct. 11-15, 1982.

Kihl, R., Appendix: Physical preparation of organic matter samples for $\mathrm{C14}$ dating, Radiocarbon date list II from Cumberland Peninsula, Baffin Island, N.W.T., Canada, Arct. Alp. Res., 7, 90-91, 1975.

Leeder, M. R. and R. I. Gawthorpe, Sedımentary models for extensional tilt block/half-graben basins, in Continental Extensional Tectonics, edited by M. P. Coward, J. F. Dewey, and P. L. Hancock, Geol. Soc. London Spec. Pub. 28, 139-152, 1987.

Machette, M. N., S. F. Personius, A. R. Nelson, D. P. Schwartz, and W. R. Lund, The Wasatch fault zone, Utah-- segmentation and history of Holocene earthquakes, J. Str. Geol., 13, 137 . 149, 1991.

Machette, M. N., S. F. Personius, and A. R. Nelson, Paleoseismology of the Wasatch fault zone -- a summary of recent investigations, conclusions, and interpretations, in Assessment of Regional Earthquake Hazards and Risk along the Wasatch Front, Utah, edited by P. L. Gori and W. W. Hays, U.S. Geol. Surv. Prof. Pap. 1500-A, A1-A72, 1992

McCalpin, J., Quaternary geology and neotectonics of the west flank of the northern Sangre de Cristo Mountains, south-central Colorado, Colo. Sch. Mines Q., 77(3), 97 pp., 1983.

McCalpin, J., Thermoluminescence (TL) dating in seismic hazard evaluations: an example from the Bonneville Basin, Utah, Proc. Symp. Eng. Geol. Soils Eng., 22nd, 156-176, 1986.

McCalpin, J., Recommended setback distances from active normal faults, Proc. Symp. on Eng. Geol. Soils Eng., 23rd, 35-56, 1987.

McCalpin, J., Current investigative techniques and interpretive models for trenching active dip-slip faults, Proc. Symp. Eng. Geol Geotech. Eng. 25th, 249-258, 1989.

McCalpin, J., and S. L. Forman, Quatemary faulting and thermoluminescence dating of the East Cache fault zone, north-central Utah, Bull. Seismol. Soc. Amer., 81, 139-161, 1991. McCalpin, J. P., W. Zuchiewicz, and L. C. A. Jones, Sedimentology of fault-scarp-derived colluvium from the 1983 Borah Peak rupture, central Idaho, J. Sediment. Petrol., 63, 120-130, 1993.

Nash, D. B., Morphological dating of degraded normal fault scarps, J. Geol., 88, 353-360, 1980. Nelson, A. R, The northern part of the Weber segment of the Wasatch fault zone near Ogden, Utah, in In the Footsteps of G.K Gilbert-Lake Bonneville and Neotectonics of the Eastern Basin and Range Province, edited by M. N. Machette, Utah Geol. Miner. Surv. Misc. Publ., 88-1, 33-37, 1988.

Nelson, A. R., Lithofacies analysis of colluvial sediments-- An aid in interpreting the recent history of Quaternary normal faults in the Basin and Range province, western United States, J. Sediment. Petrol., 62 , 607-621, 1992.

Nelson, A. R. and S. F. Personius, Preliminary surficial geologic map of the Weber segment, Wasatch fault zone, Weber and Davis Counties, Utah, scale 1:50,000, U.S. Geol. Surv. Misc. Field Stud. Map, MF-2132, 22 pp., 1990.

Nelson, A. R. and S. F. Personius, Surficial geologic map of the Weber segment, Wasatch fault zone, Weber and Davis Counties, Utah, scale 1:50,000, U.S. Geol. Surv. Misc. Invest. Map, 1-2199, 1993.

Nelson, A. R. and R. B. Van Arsdale, Recurrent late Quaternary movement on the Strawberry normal fault, Basin and Range-Colorado Plateau transition zone, Utah, Neotectonics, 1 , 7-37, 1986.

Ostenaa, D. A., Relationships affecting estimates of surface fault displacements based on scarp-derived colluvial deposits, Geol. Soc. Am. Abstr. Proprams, 16, 327, 1984

Schwartz, D. P. and K. J. Coppersmith, Fault behavior and characteristic earthquakes-Examples from the Wasatch and
San Andreas fault zones, J. Geophys. Res., 89, 5681-5698, 1984.

Scott, W. E., W. D. McCoy, R. R. Shroba, and M. Rubin, Reinterpretation of the exposed record of the last two lake cycles of Lake Bonneville, western United States, Quat. Res., 20, 261-285, 1983.

Slemmons, D.B., Geological effects of the Dixie Valley-Fairview Peak, Nevada, earthquakes of December 16, 1954, Bull. Seismol. Soc. Amer. 47, 353-375, 1957.

Stephenson, W. J., R. B. Smith, and J. R. Pelton, A high-resolution seismic reflection and gravity survey of Quaternary deformation across the Wasatch fault, Utah, J. Geophys. Res. 98, 8211-8223, 1993

Stuiver, M. and P. J. Reimer, A computer program for radiocarbon age calibration, Radiocarbon, 28, 1022-1030, 1986.

Swan, F. H. III, D. P. Schwartz, and L. S. Cluff, Recurrence of moderate to large magnitude earthquakes produced by surface faulting on the Wasatch fault, Utah, Bull. Seismol. Soc. Am. 70, 1431-1462, 1980.

Swan, F. H. III, D. P. Schwartz, K. L. Hanson, P. L. Knuepfer, and L. S. Cluff, Study of earthquake recurrence intervals on the Wasatch fault at the Kaysville site, Utah, U.S. Geol. Surv. Open File Rep. 81-228, 30 pp., 1981.

Wallace, R. E., Profiles and ages of young fault scarps, north-central Nevada, Geol. Soc. Am. Bull., 88, 1267-1281, 1977.

Wallace, R. E., Degradation of the Hebgen Lake fault scarps of 1959, Geology, 8, 225-229, 1980.

Wallace, R. E., Fault scarps formed during the earthquakes of October 2, 1915, in Pleasant Valley, Nevada, and some tectonic implications, U.S. Geol. Surv. Prof. Pap., 1274A, A1-A33, 1984

Warren, G. A. and J. P. McCalpin, Quaternary faulting on the southern Star Valley fault western Wyoming: Geol. Soc. Am. Abstr. Programs, 24(6), 67, 1992

Wheeler, R. B. and K. B. Krystinik, Persistent and nonpersistent segmentation of the Wasatch fault zone, Utah: statistical analysis for evaluation of seismic hazard, in Assessment of Regional Earthquake Hazards and Risk Along the Wasatch Front, Utah, edited by P. L. Gori, and W. W. Hays, U.S. Geol. Surv. Prof. Pap. 1500-B, B1-B47, 1992.

S. L. Forman, Department of Geology, Ohio State University, Columbus, $\mathrm{OH} 43210$

M. Lowe, Utah Geological Survey, 2363 South Foothill Drive, Salt Lake City, UT 84109

J. P. McCalpin, Department of Geology, Utah State University, Logan, UT 84322

(Received May 5, 1992 revised July 23, 1993; accepted July 28,1993 .) 